\title{
The Girl and the Feminist State? : Subjectification Projects in the Nordic Welfare State
}

\section{Oinas, Outi Elina}

Palgrave

2017-11-23

Oinas, O E 2017 , The Girl and the Feminist State? Subjectification Projects in the Nordic Welfare State . in B Formark, H Mulari \& M Voipio (eds), Nordic Girlhoods : New Perspectives and Outlooks . Palgrave , Cham , pp. 179-206 . https://doi.org/10.1007/978-3-319-65118-7_10

http://hdl.handle.net/10138/306537

https://doi.org/10.1007/978-3-319-65118-7_10

Downloaded from Helda, University of Helsinki institutional repository.

This is an electronic reprint of the original article.

This reprint may differ from the original in pagination and typographic detail.

Please cite the original version. 
Cricat ano situateo daalogue with a largely Anglo-American research dominated field of lapping fields of critical inquiry, including Nordic studies, gender (equality) studies and :al femininity studies."

edited coliection is an interdisciplinary and dialogical endeavour focused on the field ordic Girlhood Studies, It investigates young femininity as well as the key themes and epts of Girhood Studies, including girl power, feminisms, femininity, gender equality reminism and sexualities in the specific cultural, historical and political context of the lic region. The chapters of the book consist of thematic case studies, including memories ? power in the Finnish context, gendered harassment experienced and explained by Finnish troublesome girlhood within the Swedish context and girls' subjectification projects in 1c welfare state, Further, the case studies are accompanied by dialogical Outlook-essays, researchers either outside Nordic region or from adjacent research fieids reflect on ic Cirthood Studies through comparisons and reflections form their vantage point. The will be of scholarly interest to researchers and students working especially on the fields of pod Studies, Youth Studies, Cender Studies, Sociology and Cultural Studies both within the ic region and outside.

! Formark has a Ph.D. in History and is co-founder and co-ordinator of FlickForsk! Nordic 'ork for Girlhood Studies at Umeå Centre for Gender Studies, Umeă University, Sweden.

Mulari has a Ph.D. in Cultural History and is a researcher at the Finnish Youth Research ty in Helsinki, Finland.

Voipio has a Ph.D. in Literature and is a children's and youth literature researcher and

algrave acmillan

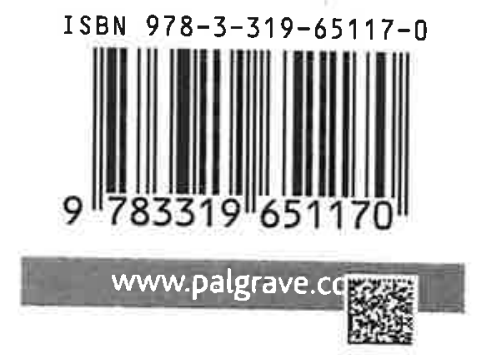

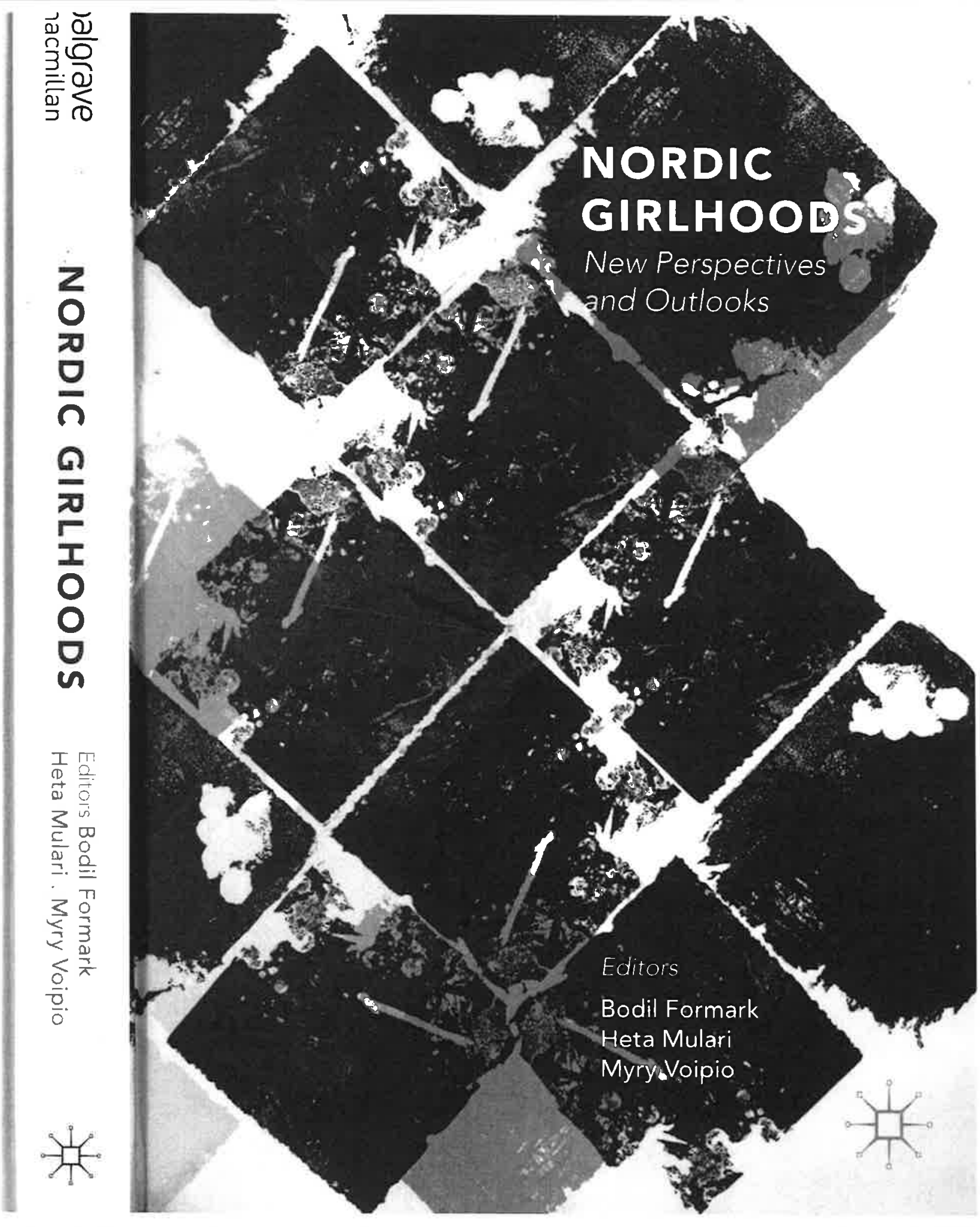


Bodil Formark · Heta Mulari · Myry Voipio Editors

\section{Nordic Girlhoods}

New Perspectives and Outlooks

\section{palgrave} macmillan 


\title{
The Girl and the Feminist State? Subjectification Projects in the Nordic Welfare State
}

\author{
Elina Oinas
}

\section{INTRODUCTION}

The Nordic girl is a remarkably well-known figure in global imaginaries, as is the Nordic state. The smart and strong girl embodying the gender equality ideal of the Nordic countries sometimes takes the shape of the beloved Pippi Longstocking figure created by Astrid Lindgren (1945) and sometimes the sexually adventurous blond girl familiar to peoplewell, let us be frank-watching porn. Smart, free, strong, and safe to be so free, are connotations that seem to embrace both these imaginary girls. The safety that enables the wild girl is, in vague ways, linked to the welfare state, the folkbemmet [the people's society]. ${ }^{1}$

Formark and Bränström Öhman (2013) suggest that the Nordic girl is marked by paradoxical opportunities and pressures that require both individual strength and social relationality in ways that should be carefully scrutinized rather than sweepingly celebrated. Contemporary girls and

\section{E. Oinas $(\square)$}

University of Helsinki, SSKH, Helsinki, Finland

e-mail: elina.oinas@helsinki.fi 
young women are expected to embody the autonomous and neo-liberal subject ideal (Sjöstedt Landen 2012), but within a system, as capable participants in the social. The Nordic model is often seen as based on a collectivist ideal but the welfare state, in contrast, can also be seen as the archetypal enabling force for a strong individualism that also characterizes the ethos of Nordic societies (Berggren and Trädgårdh 2010). Case studies, such as that of Gordon et al. (2000), reveal that there is a rich diversity in the processes of subjectification that perhaps should not be dismissed as being simply neo-liberal. It is, however, important to take seriously the ethos of liberalism, individualism, and the urge for agencystate sanctioned agency in its double meaning-as ideals that shape lives.

In what specific ways does the Nordic paradox of post-feminist idealization of achieved gender equality and neutrality, combined with a blindness regarding, and denial of, on-going conservative forces to regulate and constitute the ideal girl and its consequences, constitute actual girlhoods? While researchers have been keen to investigate the contemporary struggles to do looks, sexuality, and self in new, imaginative ways, so as to present the girl power message in a personalized manner (Ganez 1995; Saarikoski 2009; Werner 2009), here I am specifically interested in the question of context. The Nordic welfare state is one specific context, even if I am fully aware of the difficulty of pinning down a context in today's medialized and connected transnational cultures (Mulari 2015), let alone within the vagueness of the Nordic (Halsaa 2001; Loftsdóttir and Jensen 2012; Siim and Christensen 2012).

I argue in this chapter that while there is a strong research tradition on Nordic girls, there is a need for further research on specificities for which societal context is explicitly theorized. This chapter is on neither literary nor porn figures but it strives to be a sociological exploration of societal practices that frame and enable girlhoods and material subjectification by revisiting an old case study of publicly funded girls' club projects in Finland in the 2000s that I conducted with Anna Collander and Eveliina Rantanen (see Oinas and Collander 2007; Oinas et al. 2005). The clubs are a welfare state intervention to empower 12-16-year-old girls. In the weekly gatherings what is thought of as doing the girl is actively practiced and reinterpreted.

In this chapter I discuss individuality and embeddedness, but, in conclusion, will also have to pose the question: What is specifically Nordic about the named features? When we are dissecting the advantages, risks, and failures of the Nordic model, there is a risk of generating a self-congratulatory narrative that assumes an inherently essentializing Nordic categorization of societal practices that actually could be unspecific or universalizable. Nordicness sometimes occupies a discursive space that resembles notions of racialized group identity descriptions even if it is seldom problematized because Nordic is not seen as a national identity nor is it explicitly linked to whiteness (Mulinari et al. 2009). Towards the end of the chapter I discuss the risks in naming welfare state practices as Nordic by pointing to the problem this raises in relation to the similarities to nationalisms.

\section{The Welfare State and Its Diverse Promises}

The Nordic welfare state model has been in crisis since the 1990s but continues to be both celebrated as the guarantee of equality and social support, and critiqued as the authoritarian control mechanism that kills individuality (Sulkunen 2009). Subjection to the allegedly girl-friendly state has been read by the political Right as a formula for sameness and adherence to homogenizing normative expectations. The welfare state citizen is wrought by ambiguous expectations of autonomy and relationality (Näre 2005), of personal achievement ideology and commitment to a collective nationalistic anthem of belonging and passing (Svendsen 2014; Tuori 2007). Conflicting expectations can be especially heavy on young girls balancing between ideals of freedom of self-expression, yet longing for acceptance and just being normal (Oinas 2001).

Surprisingly often the safety net of the welfare state fosters achievement-oriented life-styles, even the embodied perfectionism of smart, middle-class achiever girls (Oinas 1998; Oinas et al. 2005; Oinas and Collander 2007), rather than the apathy and laziness that is often assumed by the political Right to be the outcome of the pampering state. Yet, seen as not only normative, the state is also seen to be a cherished platform for rights, individuality, and freedom, even in the domain of the intimate and the body (Bjerrum Neilsen and Rudberg 1993).

The political tension and ambivalence regarding welfare state services based on ideals of equality and universality-like education, health care, youth work, and public day-care for children-has been palpable since the recession of the 1990s. The last decade has been characterized by more right-oriented governments, a somewhat confused anti-state populist Right, and neo-liberal market rhetoric (which are not necessarily allies) taking over not only in Nordic societies but also in Europe in 
general. Research on state services as not only normative and limiting but also, in my case importantly, enabling institutions, is thus ever more crucial, not only for scholarly debate but for policy making (Lauri 2016). Does the state enable only certain ways to perform gender and citizenship? What kinds of girlhoods does the Nordic model, however imaginary, enable and demand? For whom does it do this?

Even if vastly different political perspectives flourish about how the state should liberate or regulate girls' lives, and there is no shared, harmonious agreement on how the state should interfere in shaping the lives of young people, there are certain features in professional welfare state ideals that researchers like Blomberg et al. (2010) and Wrede and Henriksson (2012) have identified. For example, respect, equality, engagement, agency, and a focus on young people's own expressions and felt needs are often mentioned (Juvonen 2014).

One potential that research on specifically Nordic girls has lies in the possibility of identifying ways of thinking beyond the binary of neo-liberal individualization and a collectivist assumption of subjectivity (Formark and Bränström Öhman 2013), a theoretical challenge that I underline here as going beyond a regional thematic. My claim here is that there is surprisingly little theoretical work on how ideas about gender and girlhoods are particular to the Nordic countries, and how the welfare state features in girls' understandings about themselves and their futures. We assume a Nordicness but have not always really studied it.

There is a strong critical research tradition on state feminism and the potential of the welfare state being particularly women-friendly (Anttonen 2002; Holmberg et al. 1966; Holter 1970; Siim and Christensen 2012; Ve 1989) but still, when we read feminist research on gender and girls in the Nordic countries, a contextualizing theorization about the specific subjectification processes that the welfare state context enables is not prominent. Nordic girls' studies scholars produce a rich plethora of high-quality empirical research that contextualizes gender and girlhoods but which draws theoretical inspiration mainly from elsewhere, like, for example, performativity theory or other AngloAmerican discussions in which the explicit state hardly features. This is in interesting contrast to the fact that there is a decidedly world-famous link between gender equality and Nordic girls in popular understandings. Such a tendency, I argue, is not incidental but has to do with theoretical underpinnings in general.
The nation state has lost its currency not only politically but also in critical academia. It bores people. The origins of this lack of excitement can be traced to the well-deserved Foucauldian critique of biopower and governmentality that leaves feminist researchers ambivalent in their stance towards the state. It could be the long-overdue connection made between the European welfare state as an idea, and nationalisms, racism, and exclusions (Bhambra 2014; de los Reyes and Mulinari 2005; Keskinen 2012), or simply the attention to globalization that renders a state structure an outdated dinosaur when actual transformations happen in more dynamic and unplanned ways (Sassen 1991). These critiques, however, do not entail that the state, if radically re-envisioned, (Bhambra 2014) as an idea and institution still would not be meaningful, even if it is only one institution among many. For feminist sociology, however, revisiting the concrete constitutive ways in which the individual is assumed to relate to the social, and is ordered by the state and public services to do so in, for example, Nordic societies, is important and should not be left unattended in the sweeping, all-embracing, universalizing conceptualization of Late Modernity (Adkins 2002; Jackson and Scott 2010; MacNay 2008; Oinas 2001). In the following section I discuss, through a public sector intervention involving the Nordic ideal girl, how the self-social relation typical of Nordic postwelfare societies is neither totally trapped in the neo-liberal ethos of self-asserting, achievement-oriented individualism, nor is it a clearly collectivist one in a Gemeinschaft, mechanic, or Soviet type of commitment to a larger unit.

\section{ReBELS AND Recognition}

In a solo interview, Stella, ${ }^{2}$ a 14 -year-old participant in the girls' club study, describes a scene in her life:

When I sit there in my class room I can look at the boy, you know, and think that "ok now he dates the girl with the right brand clothes," and you are wearing the ugly jeans. But no, "you should never mind" ... Sure.

She explains how she feels that she should be the feminist girl who is strong and proud of who she is, and never mind what the boys think. She says, "There is this enormous difference in how one should be and 
how one is." The messages she hears encourage her to think that "if they don't appreciate you they are not worth you." Even if Stella uses the phrasing "how one is" there is a sense of negotiation and malleability in how she ponders selfhood. Her account has features of performative gender combined with what Ahmed (2014) describes as a struggle between will and desire. Here, interestingly, she feels a pressure to be stronger and more independent, yet that also is an expectation; she is torn between different demands on how to perform a plausible smart girl. She should be more willful, she feels, challenging the feminist assumption, that "to be identified as willful is to become a problem" (Ahmed 3). The subject is subjectivized by a process of hailing; in the case of teenagers it is often an anonymous mass of others, often contradictory, who interpellate one as a certain subject (Butler 1990; Oinas 2001),

Stella knows that she should not care so much about other people's views, given the cultural code of individualism and well-meant ideas of individual worth, but that ideal notion of individual self-esteem does not help her when she is actually seeking the approval of the generalized gaze, or, here, of the one particular boy of her dreams. The boy probably does not even read the signs of girls' fashion that well but he is cast as the protagonist, and his interest in the cool girl is what defines Stella's failure. Another generalized gaze upon Stella's pondering on her self is what could be identified as Nordic feminism, a strong call to gain willfulness. These two seem incompatible, but what unites them is Stella seeking approval, or her desire to be bound.

Judith Butler, in her recent book, writes,

I am already bound to you, and this is what it means to be a self I am, receptive to you in ways that I cannot fully predict or control. This is also, clearly, the condition of my injurability as well, and in this way my answerability and my injurability are bound up with each other. $(2015,110)$

Butler is not referring to middle-class girls like Stella, but to precarious protesters globally. Yet the sense of being bound, sharing a vulnerability across differences, is something that could be studied through case studies on privileged girls (Oinas 2015).

Here Stella also describes the shortcomings of the old-school middleclass smart feminism, as she understands it. She should be strong and independent, she should not care about what others, especially boys, think. The girls who please boys are deemed inferior, but Stella's honest version struggles with this; she longs to be liked. She knows that feminism does not approve of her desires but, importantly, another sort of feminism provides her with the turning point of the interview. The girls' club to which she belongs discusses these notions once a week, and allows Stella to have a space in which she can relax and ponder. She says,

What is so great with the girl group is that you can, you come there once a week and there you know that everyone, or quite many, thinks like you, feel, somehow, quite uncertain. That it is not so that everyone else goes around and seems like the most beautiful in the world, as you might sometimes think.

Stella is remarkably analytical about the different pressures she identifies as part of growing up in her context. She describes a process of negotiation between her need for recognition from the boy as desirable, her will to pass as a cool-enough popular girl, and her knowledge that she should not be so needy in relation to what others think. She notes the feminist pressure to be independent and strong and the futility of such ideology in her daily struggles with self-esteem. These discussions in the interview material became familiar to us when we were conducting this study and made us believe that the groups may have enabled some of the thinking processes and articulations. What is also remarkable is the happy message of the story; a shift to a positive change in Stella's interview was made possible by a group of girls and their supportive, analytical, fun-filled collective. Stella had told us that she was rather lonely and had lost her friends when she changed school a year back. It was this group, organized by an NGO, a public service initiative typical of Finnish youth work that had made this difference to her, not a group of personal friends.

Thus, the needs of a teenager for collective support and understanding were recognized by a welfare state actor, and a project was established to help amend the problems of teenage girls. The project works with a professional youth work pedagogy of giving girls a voice, and a feminist pedagogy of collective critical analysis as a tool for dealing with contemporary youth cultures. Through this example of Stella's thoughts on girlhood I discuss what could be meant by public sector practices enabling critically distanced reflection yet socially embedded girlhoods. I revisit a Finnish case study conducted by Anna Collander, Eveliina Rantanen, and me in the early 2000s (see Oinas et al. 2005; Oinas and Collander 2007). During the 2000s girl groups were introduced 
in youth work in Sweden and quickly spread to youth work in Finland (Hanström 2001). They were initiated by state authorities and city coun cils, and sometimes by an NGO selling services to municipalities or operating semi-publicly, as in Stella's group, as a response to a worry that teenage girls needed to have specific youth work forums to combat low self-esteem, sexualization, health concerns like anorexia, and their lack of voice in the public sphere. These programs were also motivated as an investment in democracy and gender equality, since girls are youth whose self-understanding as responsible citizens needs to be strengthened (Hanström 2001).

Two different groups participated in the study during their second and, therefore, last winter as schoolgirls; the girls were turning 16 and leaving compulsory school. Most of the leaders and girls were individually interviewed, several group interviews were conducted, and the activities were ethnographically observed during their weekly meetings by one or two of the researchers (Oinas et al. 2005). The groups were rather different in their socio-economic composition, aspirations, and dynamics. The G-group consisted of middle-class girls in a wealthy Helsinki neighborhood. This club was designed to be a leisure-time club that was not targeting a specific social problem area. The six G-girls (all white) were Swedish-speaking Finns, many bilingual. The program in general has an implicit element of health promotion activity among girls prone to eating disorders and stress, but the girls in this group were not individually selected because of health concerns. The other group, the Rebels, operated in a marginalized, lowincome neighborhood outside Turku, and the girls were selected by teachers, social services, or youth workers because of their severe problems. The report of the group indicates "different difficulties in life management like self-destruction, cutting, substance abuse, stealing, school absence and conflicts at home" (Report 27 (anonymized), 2). The group leaders provided the researchers with their Reports and the girls diaries called R-log that were used as data (but not added to the list of refereces as they are not publicly available). All these participants were white; the six Rebel girls were four ethnic Finns and two from Russian-speaking homes.

\section{A Room of Their OWN}

What empowerment meant in the groups' methodologies varies, but both groups gave a lot of room to group discussions with some exercises as triggers, and the leaders' role was to be in the background. The G-group followed the original method developed in Sweden, pioneered by an Ålandic expert in explicitly feminist gender work with girls, Mia Hanström (2001).

My girl group material is meant to take up important questions in lifeeverything from love to death, economy to self-esteem. But I also put gender injustices and power at the center because I think we cheat the girls if we do not make this area visible and work with this area. (5)

The Rebels' methodology was based mainly on a widely used and appreciated, yet gender-neutral, group-building and support method from professional youth work called Myrskylyhty [storm lamp]. Its aim is to develop the participants' growth, life skills, and social skills, and strengthen their self-esteem and self-image. I will focus on the best practices we identified in the groups, but cannot claim that everything that happened in the groups was necessarily supportive or empowering for the girls (see Oinas et al. 2005).

The interviews with participants showed that in both groups the girls appreciated the project. There was a repeated ethos of putting the girls in the lead and letting them decide what happened in the group, and our observations confirmed this to be the case, even to the point where we sometimes thought that the leaders could have intervened more. But the mere fact of owning the space and the time, having a room of their own with regular meetings, snacks, and exercise opportunities, with no pressure or homework, no demands based on practicing and advancingas in the pursuit of other hobbies-was praiseworthy. Both groups highlighted careful and respectful listening and confidentiality as important rules. The girls learned, as Heidi, one of the girls in G-group, put it, to "know how important it is to listen until you finish, so that you don't get hurt." Heidi had been severely and chronically bullied and excluded in school for years and had joined the group in the hope of acquiring friends. That expectation was not met; she still felt like an outsider, and she talked about her disappointment during the interview. But she also explained that the club was important to her because she felt understood and her different views "were respected," as she phrased it, which was a new and rare experience for her. In contrast to school or to her other hobbies, here she felt safe to voice opinions about teenage girlhood that differed from what she assumed to be normal, like, for example, not being excited about pop stars. 
The middle-class G-group was clearly more oriented towards a feminist pedagogy, and they explicitly attempted to learn collectively to discuss issues that they themselves found problematic or interesting and, importantly, to try to generalize them to a societal or cultural level. The pedagogy aimed to be "personal yet not private" as one of the leaders stated in a training session that I observed. A lot of the G-group's method reminds me of the feminist consciousness-raising groups of the 1970s like, for example, the Boston Health Group (1971), but, importantly, now conducted within the welfare state regime.

Critical emancipation, health awareness, and active orientation towards democracy was an explicit goal set by the semi-public NGO that funded the projects. Our analysis of the interviews indicates that it succeeded as a public intervention to generate a politicized femininity among young girls, underlining that such a feminist agenda is a positive democratizing force. The avoidance of the too private, while still being personal, assisted in reorienting the girls' gaze away from themselves and towards the societal, but it also helped to minimize the tendency of presenting themselves as experienced, competent, and capable (Oinas 2001); this led to more openness about uncertainties, as indicated by Stella. The G-group's method of subtly avoiding discussions of actual experiences and emphasizing values and views was where the groups clearly differed.

The Rebels discussed personal events at length and the girls kept a detailed record of each other's lives, following the comings and goings of boyfriends, their hobbies, and school-related dramas. It appeared to us first as a chat group, in which personal concerns were individualized, and that could be seen as typical of contemporary youth cultures. But this group must be seen through the lens of this being a space in which the girls had a rare opportunity to be positively recognized and to have their own concerns validated by peers and, especially, by the leaders who were supportive grown-ups. The Rebel girls also noted that they actually otherwise spend little time with other girls because boyfriends were so important. The project report states that "[c]haracteristic for these girls is a certain need and longing for an adult. A shared feature in their lives is in some ways broken family background or parents' own problems (confused parenthood) that is reflected in the girls' behavior" (Report $27,2)$. Even if the girls emphasized that their major discussion topic was going through the events of the previous weekend, it clearly was of value to have a space in which each was taken seriously regardless of what had happened during the weekend. The Rebel's first leader, Johanna, was highly appreciated in the individual interviews and was called their sister, mother, and grandmother. Her care, wisdom, guidance, and wonderful back rubs were frequently mentioned and no one found the praise for Johanna uncool.

What was crucial in both groups was how the girls were encouraged to find critical attitudes to a neo-liberal just-do-it individualism that often blames the individual for personal shortcomings. For example, Julie, from Rebels, describes in a solo interview the difficulty with the usual advice.

Really, I know, you should just accept yourself the way you are, that would be the best way, but you can't really help it when at this age you have this, dammit, you could be a little skinnier and more beautiful and something like that. Then you automatically think that if you had a little self-control you would drop a few kilos. But I don't, actually I don't seriously think about looks that much.

While Julie is talking about a typical concern of teenage girls-the body and beauty ideals - she addresses the bigger issue of how to relate to societal and cultural pressure, and talks about guidance she gets to help her deal with her anxiety. Being encouraged to talk about this kind of pressure with other girls and realize that one is not alone in worrying about such things allowed the girls to view the stress related to cultural expectations from a critical distance. They were also aware that they are not able to erase or dismiss societal expectations single-handedly and that such pressures keep on shaping their lives and choices. The Rebels spent a lot of time pondering the balance between dreams and choices on the one hand, and realities on the other. The group discussions were a space for learning to rebel by critically analyzing concrete life circumstances. The repetitive discussions reminded me of Judith Butler's (1990) theory on performativity and resistance through reiteration.

Self-esteem was not seen as an individualized inner capacity but one that is learned and practiced - in the sense of the meaning of social practice (Adkins 2002; Skeggs 2004) - as well as being a rehearsed, consciously trained way of relating critically to the social environment that generates an ability to navigate it in a reflexive manner. The girls learned to analyze cultural meaning-making and, as Hey (1997) would put it, to negotiate social relationships in a collective, together. We found that 
the collective resistance through critical reflection and parodic repetitions (Butler 1990) of stereotypical femininities enabled situated agency that served to promote both democratization and health in the groups. The discussions on looks and clothes could be seen as parodic since the girls positioned themselves as not only desiring slimness but also as mocking the diet culture. In contrast to traditional understandings of health promotion projects like these, the clubs avoided normalization and the notion of disciplining and controlling aspects of health education. Instead, they generated alternative gendered and embodied performativities of Nordic girlhoods in a fun-filled and safe environment, one that will, I hope, bear the fruit of rebellious creativity in the long run (Oinas et al. 2005).

\section{Girl Power and Individual Strength}

The democratizing practice comes from the explicit agenda of learning practically how to relate to societal messages so that they are neither deterministic nor to be scoffed at. The girls were concretely trained to view their agency as potential yet always already limited. They learned that agency is embedded in the social and materialized through the constitutive forces in society, but that they are not passively at the mercy of these forces. Sometimes, however, the groups also had moments of what we called Pippi Longstocking feminism that emphasized a girl's individual capacity as an inherent, inner strength. These moments draw from the discourse of personal responsibility in overcoming any hurdles in life. In such discussions there is always the risk of implicitly blaming the individual for her sense of inadequacy. There is a peculiar alliance between the neo-liberal ethos and the strong gender-equal Nordic girl who should never mind structural, cultural, and societal injustices. While these moments were rare, it is important to note that the neo-liberal discourse loomed in the proximity of otherwise supporting spaces if the methodology did not actively resist them.

In the Rebels group the message that the girls can and should take responsibility was tempered by the warmth of the leader, which the girls found important. Without the accepting tone of care the group may have turned into a forum for competition and individualism since the girls were so obviously under pressure to excel in the few areas of life available to them, like having wild weekends, managing to skip school without repercussions, having a chain of adorable romances, and bragging about these during the meetings. My analysis of the bragging was ambivalent: it was important to let the girls choose what to bring up and to let them rule the discussion, and the leaders were admirable in neither condemning nor interfering; but there could have been a method that more explicitly encouraged the girls to work on shifting viewpoints. In this extract from a group interview, for example, we can hear the shared yet slightly competitive notion on how to perform at school:

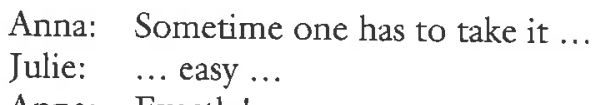

Anna: Exactly!

Julie: stay for more than six hours.

Anna: Seriously, like before the winter break, that Friday ...

Julie: I wasn't at school that day at all, so you did what?

Anna: You know, cooked up something with Jere [boyfriend at the time] ... that happens ... nothing serious ...

Letting the girls steer the agenda of the club and the discussions, and acknowledging their life situations was an important goal for the leaders who rarely talked back or criticized. In the leaders' log book one can follow their keen interest in the hardships the girls confronted in problematic homes and in their well-being, as the following entry written by a leader demonstrates:

Tina told that Julie is in the psychiatric hospital due to her self-cutting. Ellie lives temporarily in the Turvis [youth safe house]. Also Jenny is there the day hours (5-9 PM). The group is in an anxious state. (R-log, 2000, August 26)

The log reports on individual and group moods with a sense of empathy and of neutrality. It is rarely judgmental or clearly annoyed by the parents' or girls' behavior, but here it is both:

Ellie's mother called in the morning that she does not let Ellie join the trip as a punishment for the weekend's kännääminen [partying and drinking]. Anna S. and Maria did not appear, had not contacted and did not answer when phoned. Only three girls came! Lovely weather, the boat trip too. 
The day was relaxed, only the absence of the three girls bothered a little (R-log 2000, August 28)

Sometimes the girls' interest in, and their ability to deal with, their issues exceeded expectations; this is clear in an entry by a leader:

The "Interrupted Sentences" exercise surprised us. We have now clearly observed that the girls yearn for a shared discussion and pondering on "deep matters in life." We had a lot of healthy exchanges of opinions, openness. The evening passed so quickly that the renovation of $\mathrm{WCl}$ was utterly neglected! (R-log, 2001, March 3)

The Interrupted Sentences game asks the participants to complete sentences like "I am happy about ..." or "When I am older I will ...." The Rebels' program often consisted of exercises during which they discussed future possibilities. Some of the girls resisted the constant talk of the future so the astonishment in the $\log$ is founded on repeated earlier reluctance. Julie, for example, in a group interview, subtly hints at her future being too uncertain for the dreaming to be attractive:

I really don't that much like thinking of the future, or actually, I am really pissed at the thinking, like "what it carries with itself" ... So maybe I don't have the energy to dream like what I "receive in the future" either, or how would you say?

\section{Re-INVENT Yourself!}

The success of exercises that try to enhance a sense of ownership of one's life demands a careful balance, even when wishing to enhance openness and anticipation among the girls, of not going too far in burdening the individual with the responsibility of inventing herself against a realistic awareness of the actual hurdles in her life. In one of the discussions of the future a pair of new leaders tried to guide the girls towards dreams they "can influence," so they constantly imposed education, work, and happy family themes on the girls, dismissing their own dreams of big houses, daily kisses, and good nails and hair. Time and time again the girls carefully confronted the leader's agenda of the "value of a loving family" as a future plan, repeating again and again that families can hurt. Here, for example, we hear them tearing down Nina's insistence on happiness and influence.
Nina:

Those items you have listed, isn't it so that everything here you can actually influence, well except for severe illness ...?

Anna: That you can too.

Maria: $\quad$ Not necessarily. And not family either. The parents you have are what they are.

Anna: You cannot really do much about your parents, say you have an extreme catastrophe at home, so it is not like you can influence. Sure you can seek help. But in principle you can't do much about them if they are such that they burden your life, except look for help from outside. And that too does not count as good life if you can't live there or can't deal with them. Or I don't know." (Rebels meeting, 2001, October 10)

Often, when talking back, the girls added a hesitant "or ... I don't know" at the end of a sentence, in order to suggest that they do not mean to be disrespectful to the leader. These discussions were tense and there seemed to be a delicate negotiation when the leader pushed the agenda of influence and agency and the girls repeatedly reminded her of the aspects over which they had little power. Such calls for empowerment can be well meant but may also potentially burden the participant with an individualizing message that suggests the future is in her hands, while the girls seemed to be aware that this is not the case, so they end up supporting each other in reminding the leader that there is little they can do about catastrophic parenting or strict and frustrating rules at school. The conduct of this particular leader in this discussion differed from that of most of the other leaders in her inability to be present in the way that the more experienced leaders have learned to be. Their respectful approach, warmth, and skill in putting the girls and their issues first can be attributed not only to the personality of these particular leaders, but also to their professional capacity as youth workers. Sometimes, however, there could have been a clear way of interfering competently when uncertainties with regard to health and sexuality were discussed. Here, for example, in a group commenting on the questions and answers in a youth magazine's Q\&A column, the discussion turns to health awareness and how little some people know. 
Julie: Usually the questions are so stupid, so stupid. "Can a tampon, like" [gestures], something, I think is just brainless.

Anna: "I shoved a banana up my ass, is it dangerous?"

Julie: Exactly! And then the doctor replies: "Yes, dangerous indeed. You should have put a condom on."

Ellie: I remember once there was a girl who had had tampon inside and we laughed then, if you start counting, two and half.

Julie: Weeks?

Ellie: Auch!

(Rebels group discussion 2002, April 03)

It is typical for teenagers to joke about and mock ignorance, and, in such situations it is extremely hard to admit to not knowing. Here a clear method of intervening was needed if a meaningful discussion on the body was to be initiated. In the extract above we can see that in an open discussion uncertainty needed to be hidden. In the G-group practice the method explicitly guided the discussion away from personal knowledge and experiences and attempted to address issues on a more general level. For example, the girls would empathize with the authors of the letters to the youth magazine, and collectively seek reasons as to why it is hard to access information, and what the correct answers should be. The difference between the discussion about tampons above, where ignorance is ridiculed, and a more productive discussion - in which ignorance is analyzed as coming from societal conditions for girlhoods, a lack of sources of personal information, and an imperative of competence--is in the method of how the discussions are geared.

In a comparison between them, the difference between the two groups collides surprisingly smoothly with the class difference in the groups' socio-economic positions. Clearly the Rebel girls were taken seriously, but their problems tended to be individualized and not politicized, as was done through the G-group's method, perhaps out of a need not to explicitly criticize either the parents or the school. The Rebels'severe home and school problems were taken seriously by the Rebels' leaders and they clearly tried to be careful with how they dealt with these girls, but it is striking that the Rebels were not encouraged to a rebellious life the way the middle-class girls were. The middle-class rebellion, obviously, is safer. Further research is needed to investigate whether or not the more politicizing feminism of the G-group's methodology might be possible and positive for the marginalized working-class girls. Here we can only assume that shifting the gaze to a critical discussion of home environments, class, societal injustice, and school as a normative institution of control, would have been a risky path, and that the project, perhaps even unconsciously, avoided such a perspective.

The girls whose lives were already challenging were not as engaged in that which was so pleasurable for the middle-class girls-being able to shift the perspective away from their own shortcomings and to challenge, ridicule, and mock the constitutive forces of contemporary young femininity, together in a supportive group. The Rebels seem to have had such ironic and parodic discussions, too, especially when they were challenging the naivety of a new leader, as they did in some of the discussions on future dreams and health advice. Furthermore, the seriousness of the project, and the support offered for the acquisition of life skills, the development of self-esteem, and commendable future orientation were all interpreted as signs of care that the girls appreciated. Even so, the difference between how the worries of some girls (the lower-class Rebels) were turned into matters relating to their individual lives, while other girls (the middle-class G-group members) were encouraged to take ownership of a bigger picture, is striking, and deserves critical attention.

\section{INSTITUTIONALIZED EMPOWERMENT?}

This brief summary of the girl group study cannot reveal that much but I hope that it has made known my very general major point that the welfare state can establish ways of encountering citizens that allow for a positive embeddedness - a sense of being bound by the social, yet also being able to reflect simultaneously on these bonds and the discourses from a critical distance. In institutional encounters the subject is hailed into belonging, yet is also compelled to negotiate her position critically, as well as the welfare service itself. This combination of being bound and enabled at the same time is what I call embeddedness, which enables ownership and mandates a right to demand societal change. I find the concept of embeddedness captures the spirit here better than, for example, empowerment that, despite its feminist legacy, is tainted by its long history of development industry misuse in promoting neo-liberal agendas (Ampofo and Arnfred 2009).

Similar examples have been identified by other feminist scholars who study public services. Riikka Homanen's studies on maternity care $(2013,2016)$ resemble the girls' club study in some significant ways 
in terms of the argument of this chapter. Homanen's focus is on the making of the unborn, the new parent, and the state-provided expert nurse as an assemblage, a relational unit that constitute each other. She observed hundreds of hours of encounters between health-care workers, the unborn child, and the mother-to-be, often a young woman who feels lost in her new situation of pregnancy, seeking for what they thought of as the right answers. The state provides free, but actually almost obligatory, counseling for pregnant couples but, similar to my observations in the girl groups, these encounters take place in the difficult terrain between two extremes-normative control and adherence to particular idealized subject positions and practices, and a celebration of heroic individual choice discourse that may seem empowering but that pushes the clients onto a very lonely journey with a screaming baby. Homanen (2016) suggests that the welfare state demands self-reflection and selfreliance by its citizens.

In Homanen's view, the advice given manages a careful balance so that neither of these dichotomous alternatives is taken but a third option is made possible. The counseling encounter sets as its goal not taking a normative stand on behalf of the client as to what constitutes good parenthood, but attempts, rather, to facilitate contextualized and personalized reflection and practical decision making, without leaving the parents-to-be all alone. Individual decision making is contextualized, even if not explicitly politicized, as in the G-group. The maternity clinic is a publicly funded institution that enables the acquisition of expert knowledge, but Homanen observes that it refuses, remarkably explicitly, to take a moralizing or normative stand in concrete negotiations on how to cope with the pregnancy and with life with a baby. Rather, the nurses try to encourage the mothers/pregnant couples to find their own way within a framework of alternative options.

In Homanen's analysis, as in mine, the Foucauldian reading of covert disciplining and soft-looking governmentality to obedient citizenship that confirms to norms while at face value believing in personal choices, is taken into account, and is carefully considered, but not seen to have quite enough explanatory power alone. Yes, there are clients who more easily than others take to the therapeutic citizenship role that posits agency in making their supposedly own choices. Such capabilities are often tied to class and respectability. In the accounts of the parents the clinic counseling enables a heightened sense of the capacity to ponder, reflect, and choose to claim ownership of one's ideals and relationships.
Thus, it is not a neo-liberal, exhausted individual who inevitably emerges from the consultations. Rather, the services are geared to enable emerging, continuously changing citizen roles in individuals who learn to trust and rely on state services while critically evaluating them. The client spends time with a nurse discussing cultural codes, and together they seek ways of relating to each other, to the unborn and future child, parenthood, the family institution, and their different roles in society. While there clearly are encounters that fail in many ways, Homanen's analysis points to the potential in a public sector service to go beyond an either/or set-up where the citizen is inevitably a duped victim of governmentality.

A third example here is from public day-care institutions, where small children are constantly educated towards active, relational citizenship from the toddler age onwards (Paju 2013). The children are disciplined into agency, claims Elina Paju, but she detects agency that is both selfand other-oriented. The child learns to read institutional and cultural codes, to find social roles and positions, and to negotiate them. The individuality is developed in relation to rules, authorities, and peers, but not in a goal-oriented, instrumentalizing, or even intentional manner. The embodied play that is ordered and structured in the institution and given space, time, and a set of rules, is nevertheless a messy and chaotic interplay of people, space, and materiality, and can lead to unexpected outcomes. The child is at the mercy of the institution, but she or he is not powerless or institutionalized to only one template.

An interesting example from Paju's (2013) ethnography-she literally sat on the floor with the children for months-is her astonishment in the face of the girls' practice of requiring the adult caretakers' attention to help with buttons, zippers, and hair-dos. The very competent older girls' asking for help was surprising, even disappointing at first, for a feminist scholar, who appreciates explicit rebellion and strength, observing an institution that should decisively gear both girls and boys to independent, autonomous care of the self. The girls, however, had an alternative, and meaningful, agenda; they gained physical touching, care, and attachment through the seemingly needy and helpless role-play that demands respectful relationality in interaction and agency. Paju reads these scenes as evidence that agency is not necessarily individualizing, and capability does not only enhance autonomy. The day-care institution and staff who demand mainly uniformity and functionality in clothing here went along with doing girls' hair and buttoning their dresses when time allowed, 
and thus enabled a needy, incomplete subjectivity to emerge and be supported. This needy and relational, seemingly fragile other-oriented subjectivity, argues Paju (2013) in agreement with Nick Lee (2001), could be taken seriously as a theoretical challenge well beyond childhood studies.

\section{Ideal Practices and Institutional Constraint}

All these examples provide a very optimistic account regarding the welfare state's potential to enhance well-being and subjectification. The ideal version is, of course, not always the actual practice but the studies presented here are based on ethnographic observations rather than on policy documents or interviews with the experts or authorities. Weak, bad, and violent practices undeniably also happen but it is important to document ideal practices when they work well. Additionally, a special strength of public sector services is the corrective mechanisms in case of individual shortcomings among staff. A severe weakening of public institutions is possible in times of funding cuts, as has already been the case in growing kindergarten groups, lack of funding for adequate training of youth workers, or, recently in Finland, the alarming shortage of child protection social workers. The argument here is not to downplay risks, but to show that there are valuable practices worth defending; these are the babies that should not be thrown out with the bathwater of the poststructural critique of governmentality and the dangers of a rigid state.

The citizen is, from the womb, in clinic practices, in institutionalized day-care as a 1-year-old, and as a 14-year-old in the girls' club, repeatedly interpellated (Butler 1993) as a certain kind of needy, but also as a strong and active, subject. That subject is thoroughly relational, and is explicitly imagined to relate to cultural norms, rules, and regulations in a reflexive and critical manner. Of course, as Homanen (2016) writes, that self-reflexivity can also be seen as a strict requirement, and it is possible that the public authority accepts only certain choices, and not others. In none of these cases was it, however, really or only so. The institutional practices allowed for and encouraged creative choices and did not discipline transgression. What remains, however, is an imperative to situate oneself and one's individuality in a larger social setting. One is not required to stay put in one position, but must negotiate the position, and challenge it, to be a worthy citizen (Sulkunen 2009).
The girls' clubs, the maternity care, and the public day-care, ideally accommodate subjects or clients who are expected to be on their own journey but in a relationship to the societal each needs to learn to comment on, and even transform. The ideal client, then, is a critical, needy subject whose embeddedness in the social life is a crucial force in her entire becoming. The citizen is expected to demand services, she or he needs to be facilitated and supported by societal institutions, but in a way that enhances individuality but not individualism. The difference between individuality and individualism is in embeddedness. The individualistic neo-liberal agent is defined by a freedom and ethos of sovereignty, whereas individuality relies on relationality and a supportive, recognizing context.

One of the critiques of public services is that they govern the subject to a willing docility, demanding neo-liberal subjection and blind adherence to capitalist do-it-yourself freedom that is empty of any actual freedom. A feisty, angry customer is tolerated as long as she is on a personal journey to creative self-realization within the limits of consumer capitalism and very tight norms of white, middle-class decency (Skeggs 1997). Governmentality in the Foucauldian sense means that the practices I describe here are actually a disciplining force towards a quasi-freedom to adjust in one manner only, covered in a veil of individuality. This is a serious concern that probably does hit its target in many Nordic welfare state practices, and indeed was found in instances of the studies described here, for example, in some of the discussions on individualizing dreams and on the future in the Rebels group. However, what works as a counter-force is the tendency to train the girls into a politicizing thinking, which also happened in the Rebels group. The so-called client is urged to evaluate and talk back to services, institutions, and cultural norms. The clients are educated within the very same institutions to view services as practices of power that one should relate to critically.

The citizen, client, customer, or patient in welfare states is always both the disciplined subject and the singular individual, but at their best the encounters strike a balance in which the citizen experiences the joy of finding her own way, as in Stella's account. Our girl's club study shows that the threat of becoming yet another market institution disciplining to consume and brand a self is a real one, but it can be held at bay if the customers, as much as they are lured by neo-individualism, also demand otherwise. The girls demanded belonging and embeddedness even when they were most critical. The girl group girls were not only fiercely angry, 
but also laughed at their anger. They took an active relationship of critical ownership to the societal, be it pop culture, or the school, or the welfare state. They expressed a need and longing to be situated, contextualized, materialized, and subjectified through what Butler (1993) might see as their ironic, parodic repetitions of the girly girl.

Finnish childhood researchers Jouni Häkli and Kirsi Pauliina Kallio (2014) point to the difficulty scholars have in detecting a child's political agency and resistance. Their suggestion captures the spirit in a lot of girl's studies - a need to overcome the dichotomy between two extremes-where

at one end stands the subject as self-sufficient, enduring and sovereign individual, from which all consciousness and action springs. At the other end the subject dissolves into a non-sovereign product of social and discursive construction, devoid of any stability, autonomy and unity of self. (4)

What can and should be empirically studied in between is the intersubjectively constituted social selfhood that is embedded in a context upon which she or he is able to reflect. A political structure like a state, emerging through a day-care, youth, or health center, is one of the institutions in which subjectivity is constituted, possibly in meaningful and empowering ways. I may be overly positive here, and blinded by what Berlant (2011) might think of as my own cruel optimism but in the contemporary climate of anti-state politics this is my position for now.

\section{BEYOND THE NoRdic}

Having claimed that there is not enough theorizing about the specific Nordic girly subjectification processes I acknowledge that there is a lot of work gesturing towards this direction but must note, too, that it is not named in any explicit, specific ways. And yet, in the fields of gender, youth, children, and health in both the Nordic countries and elsewhere there is a strong tradition in writing the subject as relational, becoming, dependent, and needy, all in positive ways. All these fields indeed explicate a position that is critically reflexive about processes of subjectification, yet not yearning for empowerment or liberation from social bonds or embeddedness (Adkins 2002).

There are feminist scholars and political scientists across the worldTamale (2011), for instance-who emphasize the collective, yet not deterministic ways of thinking about the subject in ways that resemble some of the discussions here. While different cultures, historical contexts, and places give rise to very different ways of claiming that their specific way of managing self-social relations is unique, they often emphasize a resistance to any idea of an individualistic, independent Modern self. They assert precisely that their particular society or subculture lacks the idealization of the Modern lonely rider model of subjectivity.

Problematically, in a scenario in which Nordic feminists and, for example, African social scientists (Gqola 2015; Ratele 2016; Tamale 2011) both claim that in their particular case the foolish image of a solitary, individualized Modern Man does not apply, that very same Man is reinvoked. Empirical work demands a certain level of particularism that claims little of the entire concept of subjectivity beyond the case. But, when comparisons are made anyway, empirical particularism reintroduces the idea that there might be such free and independent figures somewhere in the masculine realm of what is known as the West. Those perceived as the others have a more collective existence.

A more helpful proposition would be to hold on to the ambition to theorize subjectivity based on empirical cases, and to chart different ways of theorizing relationality in ways that make Nordic, as well as African, embedded, relational yet reflexive subjects truly post-colonial. This means a continued theorization in which the straw Man of Modernity is seriously dismantled and no longer needed. What I have discussed here are ways in which the state in Finland has invested in services that are characterized as empowering, that use reflexivity and self-determination as their trope, but, importantly, do not promote a singular neo-liberal agenda of the simplified version of Late Modernities (Giddens 1991). This notwithstanding, I also argue that such practices can be found in many parts of the world beyond the Nordic region. No doubt what remains to be theorized, however, is the necessary difference between the here advocated embedded and incomplete subject, and the denied, broken subject of colonial, racist relations of power (Oinas et al. 2017).

Girls' studies in Nordic countries can be read as theoretical openings regarding the concept of the subject and the social. I think we should explicitly generate meaningful tools to analyze subjectification processes that are specific in a context of assumed social security, gender equality, and public support for girls, even if they are contingent and not universally available. In this chapter the girls' clubs case study shows a publicly supported feminist subjectification process that is interesting not 
because it is specific to Nordic countries but because there is a worldwide need for theorizing and explicating the urgent need of public services for young people. Health care and education are examples of public services that are historically seen as great feminist achievements, yet today are perhaps unintentionally downplayed in feminist theorizing.

A crucial issue, then, are the limits of the state and its population. The nation state is a unit that requires borders, insiders, and outsiders (Tuori 2007). Can feminist ideals of an enabling societal context be realized without an actual nation state, a strict division between $u s$ and them, and a geographically demarcated population? Does service provision require borders, insiders, and outcasts - $u s$ and others? Is the exclusiveness of what Siim and Christensen (2012) sees as the seemingly female-friendly state an unintended error that can be fixed, or is it in fact a crucial, constitutive key characteristic that reveals the limits of the model?

Ideally, critical theorizing of welfare state girlhood should, potentially, also open itself to feminist utopias of global inclusion and global citizenship with universal rights to services. If Nordic scholarship claims to be able to identify a societal structure that enables and embeds a girl in a way that empowers her not to neo-liberal individualism, but to a more collective empowerment, we should also discuss the ways in which we can open such a system to those beyond the few with citizenship and passport. A discussion about the difficulty of detaching the welfare state from its nation state-based underpinnings is long overdue.

\section{Notes}

1. The concept of the Nordic model was coined to describe the uniting fea tures of the states in the region, especially the rights-based, universal, and inclusive service system that is tax-funded and that requires a high leve of societal trust, democracy, and transparent institutions. Since such features are not unique to Nordic societies, the demarcation of Nordic can be viewed as blatantly self-congratulatory, as a romanticizing notion, and one that covers arrogant nationalism only superficially. In this chapter I discuss the geographical specificity of any model, argue against its Nordicness, and therefore, following Sulkunen (2009), systematically use the concept of the welfare state while being fully aware of its being criticized for reasons.

2. I have used pseudonyms to protect the identity of the participants.

\section{REFERENCES}

Adkins, L. (2002). Revisions: Gender and sexwality in late modernity. Buckingham: Open University Press.

Ahmed, S. (2014). Willful subjects. Durham: Duke University Press.

Ampofo, A. A., \& Arnfred, S. (2009). African feminist politics of knowledge Tensions, challenges, possibilities. Uppsala: Nordic Africa Institute.

Anttonen, A. (2002). Universalism and social policy: a Nordic-feminist revaluation. NORA, 10(2), 71-80.

Berggren, H., \& Trädgårdh, L. (2010). Pippi Longstocking: The autonomous child and the moral logic of the Swedish welfare state. In H. Mattsson \& S.-O. Wallenstein (Eds.), Swedish modernism: Architecture, consumption and the welfare state (pp, 10-23). London: Black Dog Publishing.

Berlant, L. (2011). Cruel optimism. Durham, NC: Duke University Press.

Bhambra, G. (2014). Connected sociologies. London: Bloomsbury.

Bjerrum Neilsen, H., \& Rudberg, M. (1993). Gender, body and beauty in adolescence: Three psychological portraits. Young, I(2), 32-47.

Blomberg, H., Corander, C., Kroll, C., Meeuwisse, A., Scaramuzzino, R. \& Swärd, H. (2010). A Nordic model in child welfare? In H. Forsberg \& T. Kröger (Eds.), Social work and child welfare politics through Nordic lenses (pp. 29-45). Bristol: Policy Press.

Boston Women's Health Book Collective. (1971). Our bodies, ourselves. New York: Simon \& Schuster.

Butler, J. (1990). Gender trouble. New York: Routledge.

Butler, J. (1993). Bodies that matter: On the discursive limits of "sex". New York: Routledge.

Butler, J. (2015). Notes toward a performative theory of assembly. Cambridge: Harvard University Press.

de los Reyes, P., \& Mulinari, D. (2005). Intersektionalitet: kritiska reflektioner över (o) jämlikhetens landskap. Malmö: Liber.

Formark, B., \& Brännström Öhman, A. (2013). Situating Nordic girls' studies. Girlhood studies, 6(2), 3-10.

Ganez, H. (1995). The shop, the home and femininity as masquerade. In J. Fornäs \& G. Bolin (Eds.), Youth culture in late modernity (pp. 72-99). London: Sage.

Giddens, A. (1991). Modernity and self-identity. Cambridge: Polity Press.

Gordon, T., Holland, J., \& Lahelma, E. (2000). Making spaces: Citizenship and difference in schools. New York: St. Martin's Press.

Gqola, P. D. (2015). Rape: The South African nightmare. Auckland Park: Jacana.

Häkli, J., \& Kallio, K. P. (2014). Subject, action and polis: Theorizing political agency. Progress in Human Geography, 38(2), 181-200. 
Halsaa, B. (2001). Finns det en nordisk feminism och en nordisk kvinno/genusforskning? Det norska svaret. In R. Frangeur (Ed.), Grät gärna-men forska. Rapport frän konferensen 6-7 mars 2001 om kvinnorörelse och kvinno/genusfor skning, 71-76. Linköping: Forums skriftserie.

Hanström, M. (2001). Metodikbok för "tjejverksambet". Borlänge: Björnen.

Hey, V. (1997). The company she keeps: An ethnography of girls' friendship. Buckingham: Open University Press.

Holmberg, P., Holter, H., Liljeström, R., \& Haavio-Mannila, E. (1966). Kynne eller kön? Om könsrollerna $i$ det moderna sambället. En debattskrift under medverkan av bl.a. Per Holmberg, Harriet Holter, Rita Liljeström, Elina HaavioMannila. Stockholm: Rabén and Sjögren.

Holter, H. (1970). Sex roles and social structure. Oslo: Universitetsförlaget.

Homanen, R. (2013). Doing pregnancy, the unborn, and the maternity health care institution. Doctoral dissertation. Tampere: Acta Universitatis Tamperensis 1798.

Homanen, R. (2016). Enabling and controlling parenthood in publicly provided maternity healthcare: Becoming a parent in Finland. Sociology of Health and Illness, n.p. Retrieved from http://onlinelibrary.wiley.com/ doi/10.1111/1467-9566.12491/full.

Jackson, S., \& Scott, S. (2010). Theorising sexuality. Maidenhead: Open University Press.

Juvonen, T. (2014). Fragile agencies in the making: Challenges of independent living in emerging adulthood. Young, 22(3), 253-269.

Keskinen, S. (2012). Transnational influences, gender equality and violence in Muslim families. In L. Jensen \& K. Loftsdottír (Eds.), Whiteness and postcolonialism in the Nordic countries: Exceptionalism, migrant others and national identities (pp. 73-88). Farnham: Ashgate.

Lauri, M. (2016). Narratives of governing: Rationalization, responsibility and resistance in social work. Doctoral dissertation, Umeå: Umeå universitet, Statsvetenskapliga institutionens skriftserie, 2016: 2.

Lee, N. (2001). Childhood and society. Cambridge: Open University Press.

Lindgren, A. (1945). Pippi Làngstrump. Stockholm: Rabén and Sjögren.

Loftsdóttir, K., \& Jensen, L. (2012). Introduction: Nordic exceptionalism and the Nordic "others". In L. Jensen \& K Loftsdottír (Eds.), Whiteness and postcolonialism in the Nordic countries: Exceptionalism, migrant others and national identities (pp. 1-11). Farnham: Ashgate.

MacNay, L. (2008). Against recognition. Cambridge: Polity Press.

Mulari, H. (2015). New feminisms, gender equality and neoliberalism in Swedish girl films, 1995-2006. Doctoral dissertation, Turku: Turun yliopisto.

Mulinari, D., Keskinen, S., Irni, S., \& Tuori, S. (2009). Introduction: Postcolonialism and the Nordic models of welfare and gender. In S. Keskinen,
S. Tuori, S. Inni \& D. Mulinari (Eds.), Complying with colonialism: Gender, race and ethnicity in the Nordic region (pp. 1-16). Farnham: Ashgate.

Näre, S. (2005). Styylaten ja pettäen: Luottamuksen ongelma ja postindividualismi nuorten sukupuolikulttuurissa. Helsinki: Yliopistopaino.

Oinas, E. (1998). The sexy woman and the smart girl: Embodied gender identity and middle-class adolescence. NOR A, 6(2), 78-88.

Oinas, E. (2001). Making sense of the teenage body. Turku: Abo Akademi Press.

Oinas, E. (2015). The naked, vulnerable, crazy girl. Girlhood Studies, $8(3)$ 119-134.

Oinas, E., \& Collander, A. (2007). Tjejgrupper-Pippifeminism, rosa rum, hälsofrämjande! In E. Oinas \& A.-R. Jutta (Eds.), Kpinnor, kropp och bälsa (pp. 1-292). Lund: Studentlitteratur.

Oinas, E., Collander, A., \& Rantanen, E. (2005). "Girl group" activitiesempowerment, discipline, health literacy? In T. Hoikkala, P. Hakkarainen, \& S. Laine (Eds.), Beyond bealth literacy-Youth cultures, prepention and policy (pp. 219-236). Helsinki: Finnish Youth Research Network/Finnish Youth Research Society, Publications 52.

Oinas, E., Onodera, H., \& Suurpää, L. (2017). Evasive youth, oblique politics. In E. Oinas, H. Onodera, \& L. Suurpää (Eds.), What politics? Youth and political engagements in contemporary Africa (pp. 1-19). Leiden: Brill.

Paju, E. (2013). Lasten arjen ainekset. Helsinki: Episteme.

Ratele, K. (2016). Liberating masculinities. Cape Town: HSRC Press.

Saarikoski, H. (2009). Nuoren naisellisuuden koreografioita: Spice Girls-funit tyttöyden tekijöinä. Helsinki: Suomalaisen kirjallisuuden seura.

Sassen, S. (1991). The global city. Princeton: Princeton University Press.

Siim, B., \& Christensen, A.-D. (2012). Intersectionality, citizenship and politics of belonging : Challenges to Nordic democracies. In L. Freidenvall \& M. Micheletti (Eds.), Comparisons, quotas and critical change: in bonor of Drude Dablerup (pp. 135-153). Stockholm: Department of Political Science, Stockholm University.

Sjöstedt Landen, A. (2012). A fantasy of the "ambitious young girl" as flexible knowledge-worker subject. NORA, 20(3), 249-265.

Skeggs, B. (1997). Formations of class and gender: Becoming respectable. London: Sage.

Skeggs, B. (2004). Class, self, culture. London: Routledge.

Sulkunen, P. (2009). The saturated society. London: Sage.

Svendsen, S. H. B. (2014). Learning racism in the absence of "race", European Journal of Women's Studies, 21(1), 9-24.

Tamale, S. (2011). African sexualities: A reader. Cape Town: Fahamu Books/ Pambazuka Press. 
Tuori, S. (2007). Cooking nation: Gender equality and multiculturalism as nation building discourses. European Journal of Women's Studies, 14(1), Ve, H. (1989). Kvinnor, byråkrati och välfärdsstat. Sociologisk forskning, 26(4),

Werner, A. (2009). Smittsamt: En kulturstudie av musikbruk bland tonårstjeje $r$. Doctoral dissertation, Linköping: Linköping Studies in Arts and Science.

Wrede, S., \& Henriksson, L. (2012). The making of medico-managerial

work culture in public home care for the eldicily \& M. E. Purkis (Eds.), Perspectipes on care at home for oeci, K. Björnsdóttir, 185). New York: Routledge. 